\title{
Firm Quality or Market Sentiment: What Matters More for IPO Investors?
}

\begin{abstract}
This paper investigates the investment decisions of IPO investors when equipped with information on both the quality of the firm and the market sentiment. Unique regulatory provisions allow IPO investors in India to have access to the independent assessment of firm quality and information on the participation of other investors, including institutional investors. At the same time, an active grey market reveals market sentiment before the application for subscription is closed. The results, which are robust to alternative model specifications, suggest that the institutional investors' decision is guided almost exclusively by firm quality while the retail investors' decision to participate in IPOs is strongly influenced by market sentiment, even in a highly transparent market where both sets of information are freely available.
\end{abstract}




\section{Introduction}

Although the return maximizing objective of investment strategies implies that investors' decisions to subscribe to IPO shares should depend more on the quality of the firm than on market sentiment, prior empirical evidence is mixed. Earlier studies show that institutional investors exhibit stock picking ability and their participation is positively associated with IPO performance (Field and Lowry, 2009; Chiang et al., 2010). The participation of retail investors, on the other hand, is consistent with the notion of sentiment and/or return chasing behaviour (Chiang et al., 2010), and that their sentiment is positively related to offer price (Derrien, 2005) and poor long term performance (Cornelli et al., 2006; Dorn, 2009). A reason that is often attributed to such a diverse selection is the difference in information set that the two groups of investors possess with respect to the fundamental quality of the IPO firm.

Institutional investors are considered to possess the necessary resources and benefit from economies of scale in gathering and analysing information pertinent to the fundamental quality of the IPO firm. Retail investors, on the other hand, lack access to such analytical skills, especially due to a lack of economies of scale. Therefore, the sentiment motivated trading behaviour of retail investors is attributed to their lack of information on firm quality. However, what we do not know yet is how different investors will behave if they have simultaneous access to information that reflects the fundamental quality of the firm as well as information on indicators of market sentiment at the time of making an investment decision. We examine this issue in the unique setting of the Indian IPO market where all potential investors have access to mandatory independent reports on the fundamental quality of IPO firms, information on the participation of other investors, and the indicators of market sentiment. 
As Neupane and Poshakwale (2012) note, the Indian IPO market is uniquely transparent. ${ }^{1}$ Three main features of the market are of particular relevance here. First, unlike in other countries, the IPO regulating body in India, the Securities and Exchange Board of India (hereafter SEBI), requires all IPO firms to reveal the quality of their company fundamentals through a formal and independent grading process. The quality of the IPO firm is assessed and graded by an approved credit rating agency on a scale of 1 (poor fundamentals) to 5 (strong fundamentals) and the information is made available to the investing public. Deb and Marisetty (2010) confirm that independent grading captures the IPO firm's fundamental quality including its corporate governance. ${ }^{2}$ Hence, the need to reveal the grade assigned by an independent body should help reduce the information differential between institutional and retail investors.

Second, information on the participation of investors by category (institutional, noninstitutional, and retail investors), who are allocated separate quotas of IPO shares, is publicly available on the website of the stock exchanges during the offer period (i.e. between the opening and closing dates for applications). This information should provide further signals to retail investors on how the institutional investors, who are likely to be better informed due to their access to analytical expertise, are viewing the offer. Therefore, the provision of the grading of IPOs, combined with the information on the level of participation of all parties, should help minimize the information differential between institutional and other IPO investors in India. In other words, if retail investors prefer to participate on the basis of firm quality, then they are equipped with such information.

\footnotetext{
${ }^{1}$ We provide a detailed discussion of the IPO process in India in section 2 "The salient features of the Indian IPO market”.

${ }^{2}$ Our univariate (section 4, Table 1, Panel C) and multivariate (section 5.5, Table 5) analyses reconfirm that IPOs with higher quality ratings are associated with superior performance.
} 
Finally, the Indian IPO market features a very active grey market. It begins with the disclosure of offer price range and remains active up until the day of listing (i.e. the $1^{\text {st }}$ day of trading on the stock exchange). Although the grey market is an informal (unofficial) market, the quotes (premium/discount) are reported widely in the media and are publicly available for several days before the closing of applications for subscription. The grey market premium, combined with the information on the subscription by various categories of investors, should help potential IPO subscribers to assess the demand for IPO shares and gauge market sentiment prior to submitting their own bids. Given these salient features of the Indian IPO market, the effect of information differential between institutional and retail investors on their participation should be very low compared to other IPO markets around the world. Consequently, retail investors have a strong opportunity to make their investment decisions based on firm quality rather than on sentiment and institutional investors have opportunities to assess the market demand for the IPO prior to making a decision to participate.

Using the opportunity offered by the above unique settings of the Indian IPO process and the prior evidence on the participation/performance of institutional and retail investors, we address an important issue: how the subscription levels of institutional and retail investors are affected when both types of investors have access to information on the firm's fundamental quality and market sentiment. Using a sample of 172 IPOs issued during the 2007-2011 period, we run a two horse race between proxies of fundamental quality and market sentiment to examine which has a greater influence on the participation of institutional and retail investors. We follow this up with analyses of the effects of the two sets of information (fundamental quality and investors' sentiment) on offer price, initial return, and aftermarket performance of IPOs. ${ }^{3}$

\footnotetext{
${ }^{3}$ Although Dorn (2009) reports that the purchases made by German retail investors on the first day of trading are highly correlated with their purchases in the grey market, the IPO setting in Germany does not allow
} 
Several important findings are uncovered. First, our evidence suggests a disparate participation of institutional and retail investors, even when both categories have access to identical sets of information on indicators of firm quality and market sentiment. Retail investors seem to provide greater weight to market sentiment, while institutional investors' decisions appear to be driven by firm quality. Specifically, we find that retail investors' participation is not correlated with IPO grades but influenced by investor sentiment - as proxied by the grey market premium. ${ }^{4}$ Further, retail investors’ participation shows a strong correlation with institutional investors' participation only when the latter participate well, but the relationship weakens when institutional participation declines. The participation of institutional investors, on the other hand, is consistent with the notion of informed investors their involvement is positively associated with IPO grades. Although institutional investors' participation is positively associated with the grey market premium, the relationship is not symmetric as a low grey market premium does not seem to deter them from subscribing to IPOs.

A second important finding of the paper is the relationship of aftermarket IPO performance with IPO grades and grey market premium. We find that IPO grade is positively associated with aftermarket performance. The grey market premium, on the other hand, has a negative relationship with aftermarket performance in the six months following the listing but loses its significance by the end of the first year. Finally, we also find that while IPO grade is unrelated to IPO price, the grey market premium has a positive influence on offer prices. Further, confirming the results of prior studies, we find that the grey market premium is a strong determinant of the returns on the IPO listing day.

isolating the effects of the sentiment related factors from the effects of the fundamental quality of the firm. Since investors in India have access to information on both the fundamental quality of the IPO firm and the indicators of market sentiment, the implications for investors' decisions to subscribe to IPOs can be assessed separately.

${ }^{4}$ The observed (raw) grey market premium may be influenced by both firm's grade and market sentiment; we use a residual grey market premium by regressing grey market premium on grade. We thank an anonymous reviewer for this suggestion. 
By addressing the above issues, the paper makes two important contributions to the literature. First, to the best of our knowledge, no study to date has examined the participation of institutional and retail investors in a setting where both proxies of firm fundamentals and market sentiment are freely available to investors. This comprehensive study shows the influence of sentiment and firm quality on the participation of various investor categories in a single unified framework which has been made possible by the unique regulatory settings of the Indian IPO market. Although some earlier studies (Hanley and Wilhelm, 1995; Aggarwal

et al., 2002; Chiang et al., 2010; Degeorge et al., 2010) have examined the participation of institutional and retail investors in IPOs, none of them has accounted for both the sentiment and fundamental factors simultaneously. Second, our study also contributes to the sparse literature on grey markets. However, unlike earlier studies on IPO grey markets (Cornelli et al., 2006; Dorn, 2009) we provide evidence on the effects of sentiment motivated traders on the IPO pricing (setting of offer price) and returns (initial and aftermarket) after controlling for the effect of firm quality based on company fundamentals.

The remainder of the paper is organized as follows. Section 2 summarizes some of the key features of the Indian IPO market. Section 3 discusses the related literature and develops hypotheses. Section 4 describes the samples and their key features. Section 5 presents and discusses the empirical evidence followed by the conclusions in section 6 .

\section{The Salient Features of the Indian IPO Market}

This section briefly describes the prominent institutional settings of the Indian IPO process and the grey market on which the analytical theme of the paper rests. 


\subsection{Transparency, allocation, and grading ${ }^{5}$}

There are a number of unique features of the Indian IPO process that make it distinct and transparent when compared to other IPO markets around the world. Indian IPO firms are required to reserve and allocate separate quotas of shares for three primary investor categories: institutional investors, referred to as qualified institutional buyers (QIBs), noninstitutional investors (NIIs) and retail individual investors (RIIs). The current IPO guidelines define QIBs as large institutional investors such as commercial banks, mutual funds, venture capital funds, and insurance companies who are registered with the SEBI; RIIs are those whose total bidding value does not exceed Indian Rupees (INR) 200,000. ${ }^{6}$ All other investors whose bidding value exceeds the RIIs' threshold, but are not registered as QIBs, are considered to be NIIs. The regulations require that QIBs, NIIs and RIIs are allocated about $50 \%, 15 \%$, and $35 \%$ of total shares on offer respectively. Importantly, information on the level of participation (i.e. the number of applications as well as the total number of shares applied for) by these different investor categories is made available on the website of stock exchanges throughout the offer period.

Until 2006, Indian IPO firms were primarily using a modified form of US style book-building mechanism. Since then, however, although the term book-building is still used, the mechanism resembles a uniform auction price that is similar to 'OpenIPO' used by WR Hambrecht in the US. This mechanism allows the underwriters to set the offer price within the advertised price range and subscribers receive their allocation on a pro rata basis. It does not, however, allow for any further discretion in allocation, which is a common feature in the US style IPO process. In the event of a less than full subscription in any investor category, the unsubscribed shares are re-allocated to other categories that are oversubscribed.

\footnotetext{
${ }^{5}$ For further discussion on the institutional features of the Indian IPO market, please refer to Bubna and Prabhala (2010) and Neupane and Poshakwale (2012).

${ }^{6}$ This limit was initially set at INR 25,000 in 1995 and has increased gradually over the years.
} 
Another major feature of the Indian IPO market is the requirement of mandatory grading based on the fundamental quality of the IPO firm. ${ }^{7}$ Mandatory grading, which began on May 1, 2007, requires IPO firms to undergo quality grading by designated rating agencies. ${ }^{8}$ The primary purpose of the grading, as set out by the SEBI, is to provide investors with an independent, reliable and consistent assessment of the fundamentals of the IPO firms. The grading is usually done at the time of the IPO filing (i.e. long before the issue price and issue dates are finalised) and is based on six company fundamental factors. ${ }^{9}$ The IPO firms are graded on a scale of 1 (poor fundamentals) to 5 (strong fundamentals) with a rating of 3 or more ( 2 or less) considered as firms with above average (below average) fundamentals. If the management of an IPO firm is not happy with the grade provided by an agency it can approach another agency for grading but is obliged to disclose all grades in the offer document.

\subsection{The grey market}

The Indian IPO setting also features an active grey (when-issued) market. The operation of the Indian grey market resembles the features summarised in Cornelli et al. (2006) and Dorn (2009) for European markets and involves unofficial (unregulated) buying and selling of shares of IPO firms in over-the-counter markets before the official trading of IPO shares begins on the stock exchanges (see Appendix A for an example of an active grey market period). While the opportunities to trade in the grey market (and premiums) are usually available for stocks a few days before the opening of the issue (application for subscription),

\footnotetext{
${ }^{7}$ Further information on Indian IPO grading can be found at http://www.sebi.gov.in/faq/ipograding.html (accessed on November 25, 2013). See Deb and Marisetty (2010) for further discussion on IPO grading in India. ${ }^{8}$ At the time of writing this paper, only six rating agencies are registered with the SEBI and allowed to provide IPO grading: Credit Analysis and Research Ltd. (CARE), ICRA Ltd., CRISIL House, FITCH Ratings, Brickwork Ratings India Private Ltd., and SME Rating Agency of India Ltd. (SMERA).

${ }^{9}$ The six fundamental factors noted by the SEBI (http://www.sebi.gov.in/faq/ipograding.html) are: (i) business prospects and competitive position of the company, (ii) risks and prospects of new projects, (iii) company's financial position, (iv) quality of management, (v) corporate governance practices, and (vi) compliance and litigation history.
} 
there have been instances of trading in grey markets many weeks prior to the issue opening date. This is generally the case with high profile IPO offerings. ${ }^{10}$ The grey market price and premium are widely available on specialist websites (e.g. http://www.chittorgarh.com) and in the financial press. ${ }^{11}$

Two types of quotes are available for IPO firms in grey markets. The first is grey market premium per share which is quoted in rupees and indicates the bid/ask grey market premium that brokers are willing to pay/accept over and above the issue price. This is a share deal where the seller (i.e. the IPO applicant) promises to sell the shares to the buyer should he/she receive any allocation from the IPO firm. The second quote is 'Kostak' in which the premium is quoted in rupees for a lot of retail applications. Essentially, it is a trading of IPO applications rather than the shares of the IPO firm. Appendix B illustrates the two types of grey market quotes available for Indian IPOs. Since Kostak data are only available for a small number of IPOs, we use the grey market premium in all our analyses. For the purpose of this study, the proportionate grey market premium (Grey) is calculated as in equation (1). ${ }^{12}$

$$
\begin{gathered}
\text { Grey Market Premium (Grey) }= \\
\left(\frac{\text { Grey Market Price - Mid-Point of the offer price range }}{\text { Mid-Point of the offer price range }}\right)
\end{gathered}
$$

For the purpose of our analysis we use the grey market price available after the close of the offer period.

\footnotetext{
${ }^{10}$ For example, grey market premiums of Reliance IPOs were available many weeks prior to the issue opening date.

${ }^{11}$ The nature of the grey market operation and information from specialized grey market premium websites indicate that grey market trades are carried out by retail investors.

${ }^{12}$ Since our data on the grey market premium come from publicly accessible sources (the Internet), we believe that we have the same set of information that retail and other investors participating in IPOs would have. We also scanned the message boards for a number of IPOs in a major IPO portal (www.chittorgarh.com) and found that the grey market premium features prominently in the discussions on IPO investing. Therefore, we believe that the data we have used in this paper, in spite of limited details, truly reflect the operation of the grey market in India.
} 


\section{Prior studies and hypotheses development}

The central theme of the paper is related to studies on the participation of institutional and retail investors in IPOs when they have information on the quality of the firm and market sentiments. Both Rock (1986) and Benveniste and Spindt (1989) accord significant importance to the varied participation of institutional and retail investors in their theoretical models explaining the need for underpricing. The informed participation of institutional investors is also at the heart of several studies which support book-building over other placement mechanisms (Sherman, 2000, 2005; Jagannathan et al., 2010). Past studies on US IPOs provide evidence that institutional investors receive a larger fraction of the shares in IPOs with better initial and long term performance (Hanley and Wilhelm, 1995; Aggarwal et al., 2002).

In a related study, Field and Lowry (2009) find that IPO firms with the highest levels of institutional investment significantly outperform those with the lowest levels of institutional involvement. Individual participation, on the other hand, is significantly higher in firms with poor long term performance. They further argue that the basis of superior institutional participation is due to the proper interpretation of information that is available at the time of the IPO. In the context of auction IPOs, Chiang et al. (2010) for Taiwanese and Degeorge et al. (2010) for US IPOs, find evidence of informed participation by institutional investors and return chasing behaviour of retail investors. Chiang et al. (2010) report that higher participation of institutional investors or larger institutional bids are positively associated with higher initial returns. They also argue that while institutional investors' decisions to participate are based on the value of the issue, retail investors' decisions are influenced by the returns on recent IPOs - a pattern that is consistent with the return chasing behaviour of investors. Degeorge et al. (2010) find that issuers and underwriters extract useful pricing information from investors’ bids in setting the offer price. 
In the context of Indian IPOs, Neupane and Poshakwale (2012) analyse the participation of retail and institutional investors in the transparent Indian IPO mechanism and find that while retail investors follow institutional investors they are unable to earn superior allocation adjusted returns. Their study, however, does not consider IPO grades and grey market returns. Deb and Marisetty (2010) examine the influence of IPO grades on a number of issues including underpricing, participation of retail and institutional investors and post listing performance. They report that IPO grades successfully capture several firm characteristics including the corporate governance of the firm. However, our study differs from theirs on several grounds. First, unlike Deb and Marisetty (2010), we control for the grey market information; second, we use a substantially larger sample (48 vs. 172 IPOs) adding to the reliability of estimates; and finally, we extend the model to account for the potential effects of other factors, including the level of participation of various types of investors. Our study also differs from other prior studies in that we simultaneously analyse the effects of indicators of both company fundamentals-based grading and the indicators of market sentiment that are available to investors at the time of the application for subscription. In particular, we examine which of the two factors (company fundamentals or market sentiment) has a stronger effect on institutional and retail investors’ participation in IPOs.

The view that institutional investors, compared to retail investors, hold superior information on the fundamental quality of the firm and that their participation decision is guided by such information, is based on the premise that they are able to invest substantial resources in investigating the quality of the firm due to economies of scale while this is not the case for retail investors. As noted in the previous section, however, Indian IPO investors (both institutional as well as retail) have access to information on firm quality through IPO grades as well as market sentiment. This implies that the level of information asymmetry between institutional and retail investors should be negligible in the Indian IPO market. This should 
lead to similar levels of participation by retail and institutional investors. Neupane and Poshakwale (2012), however, find that retail investors do not always follow institutional investors and suffer poor allocation adjusted IPO returns. Field and Lowry (2009) also show that while institutional investors better interpret readily available public information, individual investors either disregard or misinterpret such information. Therefore, it is still possible that retail investors are more influenced by market sentiment than by firm quality. The discussion above leads to two testable hypotheses:

$\mathrm{H}_{1}$ : Retail investors are more influenced by market sentiment than institutional investors.

$\mathrm{H}_{2}$ : Institutional investors are more influenced by firm quality than retail investors.

Our paper is also related to a strand of literature that examines the influence of grey market prices on IPO pricing, initial returns, and aftermarket (post IPO) share price performance. Cornelli et al. (2006) develop a theoretical model and, using data from 12 European markets, provide empirical evidence on the influence of grey market prices on offer price, initial returns, and aftermarket performance where sophisticated institutional investors can observe the participation of the sentiment driven investors. They report a positive relation between grey market price and final offer price, and initial returns, and a negative relation between grey market price and aftermarket performance only when the grey market price is high relative to the offer price. The associations are much weaker when grey market prices are relatively low. They further argue that the asymmetric relation is because of sophisticated institutional investors taking advantage of irrational (sentiment driven) investors when they are optimistic, but choosing to ignore them when they are pessimistic. Similarly, Derrien (2005) attributes the participation of retail investors, who are primarily driven by sentiment, to the observed positive effect of market sentiment on the offer price, initial returns and negative effect on the long term performance of IPOs. 
Aussenegg et al. (2006) explore the level of information revealed in the German grey market in relation to the information provided by book-building investors. They find that while grey market trading provides useful information for offer price setting, the information obtained from informed book-building investors cannot be overlooked either. Dorn (2009) finds a positive relation between grey market trading volume and initial returns, and a negative relationship between grey market trading volume and post-IPO returns in Germany. Together, these studies suggest the presence of significant relations among grey market valuation, offer price, initial returns, and post-IPO share price performance of the firm going public.

Derrien (2005) shows positive effects of retail investors' participation on offer price and initial returns but a reversion in market performance of IPO firms in the long term. In spite of the lack of information asymmetry between retail and institutional investors in the Indian IPO market, as noted earlier, the participation of retail investors is likely to be more influenced by market sentiment while that of institutional investors is likely to be guided by firm quality. Further, the impact of strong market sentiment is likely to obscure the influence of firm quality in the short-run, leading to a positive effect on offer price and initial returns of IPOs. However, in the long-run, the effect of sentiment should wear out and the price corrected, resulting in underperformance. On the other hand, if information on firm quality is underappreciated by the market at the time of the offer, the quality of the firm should be revealed in the long run and hence firm quality and the long term performance of IPOs should be positively related. Hence, we posit the following two hypotheses on the impact of sentiment and firm quality on offer price, and initial and after market performance:

$\mathrm{H}_{3}$ : The market sentiment has a positive effect on offer price and initial returns and a negative effect on long term performance. 
$\mathrm{H}_{4}$ : Firm quality has limited influence on offer price and initial returns but has a positive influence on the long term performance of IPO firms.

\section{The Sample}

Guided by the availability of IPO grades and grey market premiums at the time of data collection, our sample is comprised of 172 IPOs of common stocks between June 2007 and December 2011, as reported by the Bombay Stock Exchange (BSE) and/or the National Stock Exchange (NSE). ${ }^{13}$ Data on IPO firm and issue characteristics were hand collected from company prospectuses which were obtained from the Perfect Filings database. Data on IPO demand were obtained from the websites of BSE/NSE and some other finance portals, including the website of ICICI Bank (http://www.icicibank.com, one of the leading commercial and investment banks in India), Money Control (http://www.moneycontrol.com, considered to be the top finance portal in India) and Chittorgarh (http://www.chittorgarh.com, considered to be India's main IPO investment portal). Data on grey market prices were collected from Chittorgarh and GreyMarket (http://www.greymarket.co.in).

\section{Table 1 about here}

Table 1 presents the major summary statistics of the sample IPOs, the grey market premium, the participation of various investor categories and univariate analyses of post IPO performance by IPO grades and grey market premium. As shown in Panel A, the average age of the IPO firms is about 14 years, ranging between 2 and 92 years. The mean book value of total assets at the time of IPOs is about INR 7,169 million while the median value of total assets is only about INR 1,702 million. Further, the mean proceeds raised by IPO firms are about INR 3,456 million while the median is about INR 1,115 million. The distribution of both measures of the size of the IPOs (total assets and amount raised) suggests that there are

\footnotetext{
${ }^{13}$ Some stocks are listed simultaneously in both markets.
} 
more smaller IPO firms than larger ones in the sample. The mean (median) raw first day return (i.e. underpricing/initial return) for the period is $17 \%$ (9\%). The returns decline considerably over the first month of trading with the mean (median) raw return falling to $7 \%$ (-2\%). The average market return prior to IPO (Mkt3Mw) and average market volatility prior to IPO (MktVol) are 3\% and 1\% respectively. Mkt3Mw is the weighted average of the buy and-hold returns on the BSE Sensex index in the three months prior to the IPO issue opening date $t$, weights being 3 for the month before the IPO date $\left(M_{t-1}\right), 2$ for the one before $\left(M_{t-2}\right)$, and 1 for the third month before the offering $\left(\mathrm{M}_{\mathrm{t}-3}\right)$. MktVol is the standard deviation of the market returns one month prior to the issue opening date.

The statistics on oversubscription suggest that demand for IPO shares is highly variable, ranging from undersubscription to extremely high oversubscription (159.4 times) with a mean of about 17 times the amount offered. The average (median) offer price relative to the offer price range is $0.83(1.00)$ which suggests that most of the issues are priced at or near the upper cap of the offer price range. The average (median) initial return of IPOs listed during the two months prior to the offer period (PriorIR) is about 22\% (19\%). The average (median) underwriter reputation (LbmRep) is 0.45 (0.00) which suggests that most IPOs in our sample are managed by less reputed underwriters. The average (median) grey market premium (Grey), for our sample, measured as in equation 1, is 18\% (7\%). Although there are some IPOs with the highest quality rating (4 or 5), the mean (median) IPO grade is 2.57 (2), indicating that most sample IPO firms have weak to average fundamentals.

Panel B (Table 1) shows the participation of investors by their categories. The median IPO is oversubscribed by about 3 times in all three categories of investors. Nevertheless, there is a significant variation in participation across the IPOs and by investor categories; the oversubscription rate of institutional investors (2.08 times) was modest compared to those of non-institutional and retail investors (more than 3 times). The institutional investors' quota 
was undersubscribed in 30\% of cases while only 1 in 8 IPOs were undersubscribed by noninstitutional investors and less than 25\% of the IPOs were undersubscribed by retail investors. More importantly, however, investors from different categories do not appear to undersubscribe the same set of IPOs. Retail investors undersubscribe only 13 of the 56 IPOs that were undersubscribed by the institutional investors, implying that the retail investors do not always follow the institutional investors when it comes to subscription to IPOs. From the rate of over/undersubscriptions, it appears that institutional investors are more cautious than other investors.

Panel C (Table 1) documents the post listing market adjusted ${ }^{14}$ performance of IPOs by grade and residual grey market premium. To avoid the joint effect of IPO grade and market sentiment on the magnitude of grey market premium, we regress the observed grey market premium (Grey) on IPO grade and use the residuals (GreyRes) as the measure of market sentiment. For analysis of the post listing performance by grades, we segregate the IPOs into two groups: IPOs with below median grades (below 3) and IPOs with equal to or above median grades ( 3 or above). Of the 172 sample IPOs for which we have grades, 88 are rated below median while the rest (84) are rated equal to or above median. The below median IPOs are smaller in size measured by both total assets and the amount raised. Consistent with hypothesis 4 , the normalized offer prices of the two IPO groups are not significantly different from each other. We calculate the first day and first month returns from the offer price, while the 3 month, 6 month and 12 month returns are calculated from the price at the end of the first month of listing. While the first day and first month returns are significantly positive for the overall sample, the post listing performance of the overall sample is significantly negative. Three, 6 and 12 months' market adjusted returns (using BSE 500), calculated from the price

\footnotetext{
${ }^{14}$ The first day and first month returns are adjusted using the BSE Sensex index, while the 3 month, 6 month and 12 month returns are adjusted using both the BSE Sensex and the broader BSE 500 index. BSE Sensex is an index representing 30 well-established companies listed on the Bombay Stock Exchange. BSE 500 is an index of 500 stocks representing nearly 95\% of the total market capitalization of the Bombay Stock Exchange.
} 
at the end of the first month of listing, are $-7 \%,-8 \%$ and $-14 \%$ respectively, all significant at the less than $1 \%$ significance level. Although there are some differences in the initial returns of lower and higher grade IPO firms, the difference is not statistically significant. In the post listing period, however, issues with superior grades significantly outperform those with inferior grades. For instance, the median 3 month, 6 month and 12 month post listing BSE 500 adjusted excess returns of IPOs with above average grades are significantly higher by about $11 \%, 18 \%$ and $15 \%$ respectively compared to those of IPOs with below average grades. Overall, consistent with our hypothesis, the analysis of IPO performance by their grades suggests that the grading of IPOs in India appears to be a reasonable proxy of the quality of the IPO firm, even before other features of the IPO are controlled for.

In Panel C we also categorize 172 sample IPOs into two groups by median residual grey market premium. Accordingly, we have 86 IPOs with below median and 86 IPOs with equal to or above median residual grey market premiums. There are no significant differences in their total assets and the proceeds raised. Further, consistent with hypothesis 3, the normalized offer price of IPOs with higher grey market premium is significantly higher than that of IPOs with lower grey market premium. We find that while IPOs with equal to or above median residual grey market premiums perform significantly better than those with below median premiums on the first day and in the first month of listing, the difference reverses significantly within the first six months and becomes insignificant within the first year of listing. Overall, the univariate analysis suggests that while high IPOs' grades are associated with superior aftermarket performance, the same cannot be said about grey market premiums, indicating that grey market premiums are possibly driven by investors' sentiments rather than company fundamentals. We return to this issue in section 5.5 where we examine their effects on the post listing performance of IPOs in a multivariate framework after controlling for the effects of other variables that are known to affect IPO returns. 


\section{Empirical Results}

\subsection{Retail investors’ participation}

Earlier studies (e.g. Derrien, 2005) provide evidence consistent with the notion that the decisions of retail investors to participate in IPOs are guided by sentiment. However, unlike in other markets, the Indian IPOs' investors have access to information that proxy both company fundamentals and market sentiment, which can be used in investment decisions. Under the pretext of enhanced transparency of the Indian IPO market, this sub-section tests our first hypothesis that 'retail investors are more influenced by market sentiment', examines the determinants of retail investors' participation and identifies the source of information (company fundamental versus market sentiment) that has a stronger impact on the decision of retail investors. To this end, retail investors' participation is modelled as a function of the two sets of information and a host of control factors that are known to affect investor participation on IPOs, as shown in equation (2).

$$
\begin{aligned}
& \text { RII }_{\text {closing,j }}=\beta_{0}+\beta_{1} \text { Grade }_{j}+\beta_{3} \text { QIB }_{\text {penul }_{j}}+\beta_{3} \text { GreyRes }_{j} \\
& +\beta_{4} M k t 3 M w_{j}+\beta_{5} M k t V o l_{j}+\beta_{6} \text { PriorIR }_{j} \\
& +\beta_{7} \operatorname{LbmRep}_{j}+\beta_{8} \operatorname{LnGpcds}_{j}+\beta_{9} \operatorname{LnAge}_{j} \\
& +\sum_{k=1}^{11} \beta_{k} \text { Industry }+e_{j}
\end{aligned}
$$

The dependent variable $\mathrm{RII}_{\text {closing, }}$ is the natural log of 1 plus the oversubscription of retail investors at the end of the offer period. Among the explanatory variables, the quality of the firm ( $\mathrm{j}$ ) is represented by two variables: the rating (Grade) of the firm given by the independent credit rating agency, and the institutional investors' participation (QIB $\left.{ }_{\text {penul }}\right)$ measured as the natural log of 1 plus the institutional investors' oversubscription on the penultimate day of the offer period. We use the penultimate day's subscription to capture the 
impact of institutional participation on retail subscription. ${ }^{15}$ The sentiment of other market participants that can affect the retail investor's confidence and sentiment is represented by the residual grey market premium (GreyRes). As discussed earlier, to avoid the joint effect of IPO grade and market sentiment on the magnitude of grey market premium, we use residual grey market premium (GreyRes) as the measure of market sentiment. Other explanatory variables in the equation are recent market return (Mkt3Mw), recent market volatility (MktVol), average initial return of IPOs listed during the two months prior to the offer period (PriorIR), the underwriters' reputation (LbmRep), the size of the issue (LnGpcds, i.e. natural $\log$ of gross proceeds) and the age of the firm (LnAge, i.e. natural log of 1 plus the age of the firm in years).

\section{Table 2 about here}

To examine whether the relationship between the participation of retail investors and the institutional investors in IPO and the sentiment investors in the grey market is symmetric, we extend equation (2) to include interactive variables, as in Cornelli et al. (2006). First, institutional investors' participation is interacted with an indicator function that equals 1 if the penultimate day's institutional investors subscription is equal to or above its median over the entire sample and 0 otherwise $\left(\mathrm{QIB}_{\text {penul }} \mathrm{x}\right.$ Indicator). ${ }^{16}$ Second, the variable 'GreyRes $\mathrm{x}$ Indicator' represents the interaction between the residual grey market premium and an indicator variable that takes the value of 1 when the residual grey market premium is equal to or above its median (grade of 3 and above) over the entire sample and 0 otherwise. Equation (3) is estimated in a nested regression form using OLS after controlling for the industry fixed effects (11 industry groups) and the estimates are presented in Table 2.

\footnotetext{
${ }^{15}$ As a robustness test we also used the final overall institutional subscription instead of the penultimate day's subscription. Results remain qualitatively similar.

${ }^{16}$ The median value of institutional investors' penultimate day's subscription is 0.995 which means our sample is neatly categorised into two groups of over and undersubscribed IPOs.
} 
Specification (1) shows that while the coefficient of 'Grade' is positive, it is not statistically significant, indicating that the retail investors' participation is not dependent on the quality of company fundamentals. Next, we introduce the grey market premium (GreyRes) in specification (2), the participation of institutional investors ( $\left(\mathrm{QIB}_{\mathrm{penul}}\right)$ in specification (3) and both in specification (4) to assess how the retail investors are affected by other parties' views on the IPO. The coefficients of both variables in all three specifications are positive and highly significant, depicting their strong influence on the participation of retail investors. Moreover, the size of the effect of the grey market premium (GreyRes) is much higher than that of institutional investors. This result is consistent with our hypothesis that despite the presence of some measure of firm quality, retail investor participation will be influenced by the sentiment of the market.

To test whether the two variables (grey market premium and institutional investors' participation) have a symmetric relationship with retail investors' participation, we introduce the aforementioned interactive terms in specification (5). While the coefficients of both the grey market premium and institutional participation remain positive and statistically significant, the coefficients of the interactive terms suggest a different story. The coefficient of the grey market premium indicator (GreyRes $\mathrm{x}$ Indicator) is insignificant, implying a symmetric relationship between the grey market premium and retail investors’ participation. The institutional investors' participation indicator ( $\mathrm{QIB}_{\text {penul }} \mathrm{x}$ Indicator), however, is positive and statistically significant, suggesting that the relationship is asymmetric. This means the impact of institutional participation is not as strong on retail participation when institutional investors undersubscribe.

Although the participation of institutional investors is expected to signal the quality of the firm, the estimates suggest that retail investors appear to pick and choose between the information content in the grey market premium and institutional investors' participation. 
More precisely, when institutional investors participate extensively, retail investors tend to follow them, but when the former participate less, retail investors over-weight the information content in the grey market premium and under-weight the information content in the institutional investors' participation. These patterns imply that retail investors are generally driven by indicators that signal optimism. To examine the robustness of the results, in specification (6) the dependent variable, oversubscription (the measure of retail investors' participation), is replaced with the number of bids made by retail investors (natural log of 1 plus the number of bids). The quality of the results remains the same as in specification (5), reconfirming the asymmetric influence of institutional investors' participation on the retail investors' decision to subscribe to the IPOs.

Among the factors that can shape the confidence of retail investors, pre-IPO market returns (Mkt3Mw) and prior IPO returns (PriorIR) have positive and statistically significant relationships with retail investors' participation, indicating that retail investors tend to extract signals from historical returns. However, retail investors do not seem to be influenced by the underwriters' reputation. In all specifications, the coefficients of most other control variables have expected signs and significance. The negative coefficient of the size of the issue implies that retail investors' oversubscription rate declines with the increase in the size of the issue, possibly due to the limited absorption capacity of the retail investors to subscribe to all the shares allocated to them. The negative and significant coefficient of the volatility of pre-IPO market returns suggests that retail investors are reluctant to participate in IPO subscription when the market is experiencing high volatility. Overall, the estimates suggest that the retail investors' decision to participate in an IPO depends more heavily on the indicators of sentiment than on the indicators of the fundamental quality of the firm. 


\subsection{Institutional investors’ participation}

To test our second hypothesis that 'the institutional investors' decision to participate in an IPO is influenced more by firm quality than by market sentiment', institutional investors' oversubscription is regressed against the measure of firm quality (Grade) and several indicators of market sentiment, as described in equation (2) (see sub-section 5.1). The estimates are presented in Table 3. In specifications (1) and (2) the dependent variable ( $\left.\mathrm{QIB}_{\text {closing }}\right)$ is the institutional investors' oversubscription rate as on the final day of the offer period measured and in specification (3) we replace the dependent variable, oversubscription rate, with the number of bids made by institutional investors (the natural log of 1 plus the number of bids) as at the end of the offer period.

\section{Table 3 about here}

The results (Table 3, all specifications) show that, unlike retail investors (Table 2), institutional investors' participation is significantly and positively affected by the fundamental quality of the IPO firm (Grade). The evidence that institutional investors participate well in good quality IPOs is consistent with the previous findings (Aggarwal et al., 2002; Chiang et al., 2010) and supports the view that institutional investors are better informed than retail investors, possibly due to their access to analytical expertise.

The positive and significant coefficients of the measures of the grey market premium (GreyRes) suggest that institutional investors extract signals from the grey market and use these in their participation decision. This is consistent with the view of Cornelli et al. (2006) that when the grey market premium is high, institutional investors would find it easy to offload their subscription to investors who are driven by their optimism. Moreover, the coefficient of the measure of firm quality (Grade) continues to remain positive and significant even after controlling for the effects of the grey market premium, suggesting that even when 
the high grey market premium is indicating the presence of optimistic traders in the markets, the institutional investors do not undermine the importance of firm quality while deciding to participate.

To examine whether the effects of firm quality (Grade) and the grey market premium on institutional investors' participation is symmetric, we include additional interactive terms in the specification. First, an indicator variable that takes the value of 1 for IPOs with a grade equal to or above the median grade (3 or higher) and 0 otherwise is created and interacted with the IPO grade variable (Grade x Indicator). Second, a residual grey market premium indicator that takes the value of 1 for the IPOs with a residual grey market premium equal to or higher than the median premium and 0 otherwise is created and interacted with the residual premium (GreyRes x Indicator). The estimates in specification (2) show that the coefficients of grade indicator (Grade $\mathrm{x}$ Indicator) are insignificant, suggesting that the effect of IPO quality on institutional participation is symmetric. The coefficient of the residual grey market premium indicator, however, is positive and statistically significant, which suggests an asymmetric influence of the grey market premium on institutional investors' decision to participate.

More specifically, while a high grey market premium leads to higher participation of institutional investors, low grey market premiums do not necessarily deter them from subscribing to the high quality IPOs. Further, the insignificant effects of initial returns of prior IPOs and market volatility on institutional investors' participation reassures us that institutional investors are not driven by historical factors in the market. In specification (3), the dependent variable is replaced by the natural log of 1 plus the number of bids on the final day of application for subscription. The quality of the results remains robust. Among other variables, the size of the issue, underwriter's reputation and the recent trend in market returns generally appear to influence the participation of institutional investors. 
Overall, the symmetric effect of the quality of the firm, the asymmetric effect of the grey market premium and a lack of significant effects of prior returns on IPOs, confirm that the institutional investors' decision to participate is not driven by market sentiment while the sound fundamental value of the firm is critically important. Further, since the economic significance of 'grade' is almost twice that of the grey market premium in explaining institutional participation, the results are consistent with the second hypothesis and with the notion that the sound fundamental value of the IPO firm is critically important in order to attract institutional investors. ${ }^{17}$

\subsection{The setting of IPO offer price}

The discussions above establish that both the retail and institutional investors extract signals from the grey market premium. Since IPO firms are required to set the offer price while the grey market is active, it is likely that the IPO firm also accounts for the signals from the grey market in setting the offer price. Cornelli et al. (2006) show that grey market prices have a significant influence on the offer price setting of European IPOs. The European grey market traders, however, do not have access to information on the participation of other traders. Consequently, the grey market price, which remains independent of information on participation, could be an additional (independent) source of information for IPO firms. In this sub-section, we examine part of our hypotheses 3 and 4 which predict a positive relation between market sentiment (grey market premium) and offer price and an insignificant relationship between firm quality (IPO grades) and offer price. We do so by regressing the offer price normalized by the offer price range, as in Cornelli and Goldreich (2003), ${ }^{18}$ against a set of explanatory variables including grey market premium (GreyRes), IPO grades (Grade)

\footnotetext{
${ }^{17}$ A $10 \%$ change in the median value of grade is associated with a $5.91 \%$ change in institutional investors' participation but a $10 \%$ change in the median value of the residual grey market premium is only associated with a $2.68 \%$ change in institutional participation.

${ }^{18}$ Normalization of the offer price converts it to a scale of 0 to $1 ; 0$ if the offer price is set at the lower bound of the price range and 1 if the offer price is set at the upper bound.
} 
and the participation of the three investor groups (the natural log of 1 plus oversubscription) as in equation (3).

$$
\begin{aligned}
& \text { OfferPrice }_{j} \\
& =\beta_{0}+\beta_{1} \text { GreyRes }_{j}+\beta_{2} \text { Grade }_{j}+\beta_{3} \text { QIB }_{\text {closing }_{j}}+\beta_{4} \text { NII }_{\text {closing }_{j}}+\beta_{5} \text { RII }_{\text {closing }_{j}} \\
& +\beta_{6}{\text { Mkt } 3 M w_{j}}+\beta_{7} \text { MktVol }_{j}+\beta_{8} \text { LnGpcds }_{j}+\beta_{9} \text { LnAge }_{j}+\beta_{10} \text { LbmRep }_{j} \\
& +\beta_{11} \text { PriorIR }_{j}+\sum_{k=1}^{11} \beta_{k} \text { Industry }+e_{j}
\end{aligned}
$$

Since the offer price has to be set within the original offer price range, equation (3) is estimated using Tobit regression with censoring from above and below. QIB ${ }_{\text {closing, }}$ NII $_{\text {closing }}$ and RII $_{\text {closing }}$ are the natural log of 1 plus the institutional, non-institutional and retail investors' oversubscription respectively as on the final day of the offer period. The estimations also account for the quality of the firm (Grade), reputation of the underwriters (LbmRep), the size of the issue (LnGpcds), age of the firm (LnAge), recent market returns (Mkt3Mw), recent market volatility (MktVol), prior initial returns (PriorIR) and industry fixed effects (11 industry groups).

\section{Table 4 about here}

The estimates of the determinants of offer price setting (equation 3) are presented in Table 4 (specifications 1 and 2). Specification (1) examines the effect of the grey market premium on offer price without accounting for investors' subscription. The estimates show that, as in European markets (see Cornelli et al., 2006), the grey market premium exerts a positive and significant effect on the offer price of Indian IPOs. The effect of firm quality (Grade), however, is insignificant. Specification (2) is extended to include the variables representing the oversubscription level of all three categories of investor. While the coefficients of the variables representing the subscriptions of retail and institutional investors are positive and 
significant, the coefficient of the grey market premium retains its significance. This is consistent with Cornelli et al. (2006) as well as our hypothesis on the impact of grey market premium on offer price. As hypothesized earlier, the coefficient of 'Grade' remains insignificant, indicating that in the presence of market sentiment firm quality has a limited effect on offer price. Overall, the estimates in Table 4 suggest that, as in European IPO markets, the grey market premium has a significant impact on setting the offer price of Indian IPOs.

\subsection{IPO initial returns}

In equilibrium, the grey market premium should be the difference between the offer price and the equilibrium price of the shares on offer. If the market is able to assess the quality of the firm then the initial returns (underpricing) and grey market premium, as predicted by hypothesis 3, should be positively associated. To examine hypotheses 3 and 4 on the relationship between firm quality and market sentiment with initials returns, we regress market-adjusted first day IPO returns (MIR $)$ against a set of explanatory variables (equation 3) using OLS. The dependent variable, $\mathrm{MIR}_{1}$, is the excess initial return measured as the first day return ( $1^{\text {st }}$ day closing price minus offer price divided by the offer price) less market return (i.e. change in BSE Sensex) during the same period. The explanatory variables include final residual grey market premium (GreyRes), three variables (QIB ${ }_{\text {closing, }}$ NII $_{\text {closing }}$ and

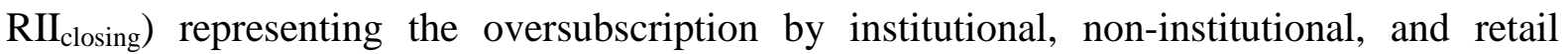
investors, the fundamental quality of the firm (Grade), the offer size (LnGpcds), age of the firm (LnAge), underwriter reputation (LbmRep), recent market return (Mkt3Mw), recent market volatility (MktVol) and prior initial returns (PriorIR). The estimates are reported in specification (3) in Table 4. 
Consistent with the prediction of our hypothesis 3 and the findings of prior studies (Aussenegg et al., 2006; Cornelli et al., 2006; Dorn, 2009) the estimates reveal a positive and significant relation between the grey market premium and initial returns. The estimates also show that neither IPO grades nor the participation of any type of investor have any significant effect on initial returns. Consistent with earlier studies, we find a positive relationship between initial returns of prior IPOs (PriorIR) and initial returns. The coefficients of other control variables such as the offer size, recent market returns (Mkt3Mw) and volatility (MktVol) are insignificant.

\subsection{Aftermarket returns}

If the traders in the grey market were to be guided by unsustainable optimism rather than by the equilibrium value of the shares, then the positive relation between the grey market premium and excess return should be short-lived. Consequently, as predicted in hypothesis 3, the grey market premium and aftermarket returns should be inversely related as the market corrects for its initial optimism. Moreover, if IPO grade truly reflects the quality of the firm, there should be a positive relationship between the grade and aftermarket returns (hypothesis 4). To examine these issues, we regress aftermarket returns against the residual grey market premium and IPO grades with other possible determinants of the long term performance of IPOs as in equation (4).

$$
\begin{aligned}
& \text { AfterMarket Returns } \\
& =\beta_{0}+\beta_{1} \text { GreyRes }_{j}+\beta_{2} \text { Grade }_{j}+\beta_{3} \text { QIB }_{\text {closing }_{j}}+\beta_{4} \text { RII }_{\text {closing }_{j}} \\
& +\beta_{5} \text { LnGpcds }+\beta_{6} \text { LnAge }_{j}+\beta_{7} \text { LbmRep }_{j}+\beta_{8} \text { PriorIR }_{j} \\
& +\sum_{k=1}^{11} \beta_{k} \text { Industry }+e_{j}
\end{aligned}
$$


To measure the aftermarket performance we compute the market adjusted buy and hold returns (as in Dorn, 2009) for 3 month, 6 month and 12 month holding periods starting at the one month anniversary of the IPO. Two alternative market indices (BSE Sensex index, BSE 500 index) are used to measure the market return. BSE Sensex is the most popular and widely followed index representing almost 30 liquid stocks while BSE 500 is a broad-based index that comprises 500 stocks on the BSE. The two main variables of interest are the fundamental quality of the firm (Grade) and the residual grey market premium (GreyRes). The model also controls for participation of institutional investors $\left(\mathrm{QIB}_{\text {closing }}\right)$, underwriter reputation (LbmRep), offer size (LnGpcds), age of the firm (LnAge), prior initial returns (PriorIR) and fixed effect of 11 industry sectors. The results are presented in Table 5.

\section{Table 5 about here}

Consistent with the findings of previous studies (Cornelli et al., 2006; Dorn, 2009) and the prediction of our hypothesis 3, the estimates in Table 5 reveal an inverse relationship between the grey market premium and aftermarket performance of IPOs in the six months after listing. The relationship loses its significance in the 12 months' aftermarket regressions. The results presented in Table 5, combined with those in specification (3) of Table 4, suggest that IPOs with a high grey market premium exhibit extremely volatile price performance in the post listing period. Driven by sentiment, these IPOs exhibit prices above the fundamental value in the first month of listing and then crash dramatically in the following six months. These estimates suggest that investors who invest in IPOs with a higher grey market premium are likely to suffer significant losses within the first six months. However, the insignificant coefficient of the grey market premium on 12 month returns, when controlled for firm quality, indicates that the influence of market sentiment fades away as the quality of the firm becomes more visible. 
On the other hand, consistent with the predictions of hypothesis 4, the coefficient of IPO grade is positive and statistically significant in all specifications. In the model of 3 month post IPO-returns, the coefficient is only marginally significant but becomes stronger for 6 month and 12 month holding period returns. The coefficient of institutional investors' participation is not significant at any conventional level. Since IPO grade and institutional participation are highly correlated, the effect of institutional participation is possibly captured by IPO grades. Moreover, since institutional participation is influenced by both investor sentiment and firm quality (as shown in Table 3), and the sentiment and firm quality have opposing effects on long-run performance, it is not surprising that institutional participation does not have a significant effect on long-run performance. The coefficient of retail investors' participation is not statistically significant at any meaningful level. It is likely that the grey market premium in the equation, the main proxy for sentiment, reduces the significance of the impact of retail investors' participation in the long-run return regressions. ${ }^{19}$ Overall, the estimates support the predictions of our hypotheses 3 and 4. Further, the observed positive association between IPO grade and aftermarket returns and the negative relationship between grey market premium and aftermarket returns suggest that retail investors can increase their returns by switching their IPO participation strategy in favour of IPO grades instead of the signals derived from market sentiment (grey market premium).

\section{Conclusions}

Extant literature suggests that institutional investors' decision to participate in the IPO process is guided by firm quality while that of retail investors is driven by market sentiment. This discrepancy is often attributed to the ability of the institutional investors to analyse the firm quality while it is not cost effective for retail investors to follow suit. Hence, they follow

\footnotetext{
${ }^{19}$ It is noteworthy that when grey market premium (GreyRes) is excluded, the coefficient of retail investors' participation becomes negative and statistically significant in most of the specifications.
} 
the market sentiment often with adverse post listing performance. The regulatory provisions and presence of an active grey market make the Indian IPO market uniquely transparent and provide a base for natural experiments to test whether retail investors' market sentiment driven decision is actually caused by their inability to analyse the company fundamentals and assess the firm quality. Unlike in other countries, all IPO investors in India have access to firm quality grade provided by independent assessors and indicators of market sentiment before lodging an application for subscription. This unique setting offers an opportunity to test whether retail investors attach greater weight to firm quality than to market sentiment when faced with both sets of information. Using the information contained in independent grading of IPO firms, the level of participation of institutional investors, premiums in the grey market, and aggregate market performance around the issue, this paper examines the relative strength of the sentiment and company fundamentals-based grading on the participation of retail and institutional investors.

Several conclusions emerge. First, in deciding their participation, retail investors seem to attach greater weight to market sentiment than to the fundamental quality of the firm. Retail investors' participation is strongly correlated with institutional participation when the latter participate well but the relationship weakens when institutions do not participate so well. Retail investors' participation also remains independent of IPO grades. These findings challenge the view that retail investors decide on sentiment because of the lack of information on firm quality. Second, the participation of institutional investors is positively associated with the fundamental quality of the firm. Although the institutional investors' subscription is positively associated with grey market premium, the relationship is asymmetric; they tend to participate more when the premium is high but the low premium does not appear to deter them. Third, consistent with the evidence in the literature, the grey market premium has a positive effect on both offer price and initial returns. Fourth, the participations of institutional 
and retail investors appear to positively influence the offer price (within the regulatory constraints) but their ability to explain the initial returns remains limited. Finally, the aftermarket performance of IPOs is inversely related to the grey market premium while it is positively associated with IPO grades, indicating the market tends to overreact to investor sentiment but underreact to IPO quality at the time of the offer. Overall, the evidence suggests that institutional investors' decisions are influenced by firm quality while those of retail investors are driven by market sentiment, even when all of them have access to indicators of both firm quality and market sentiment. 
Appendix A

The timeline of an Indian IPO (Orient Green Power Company Ltd)

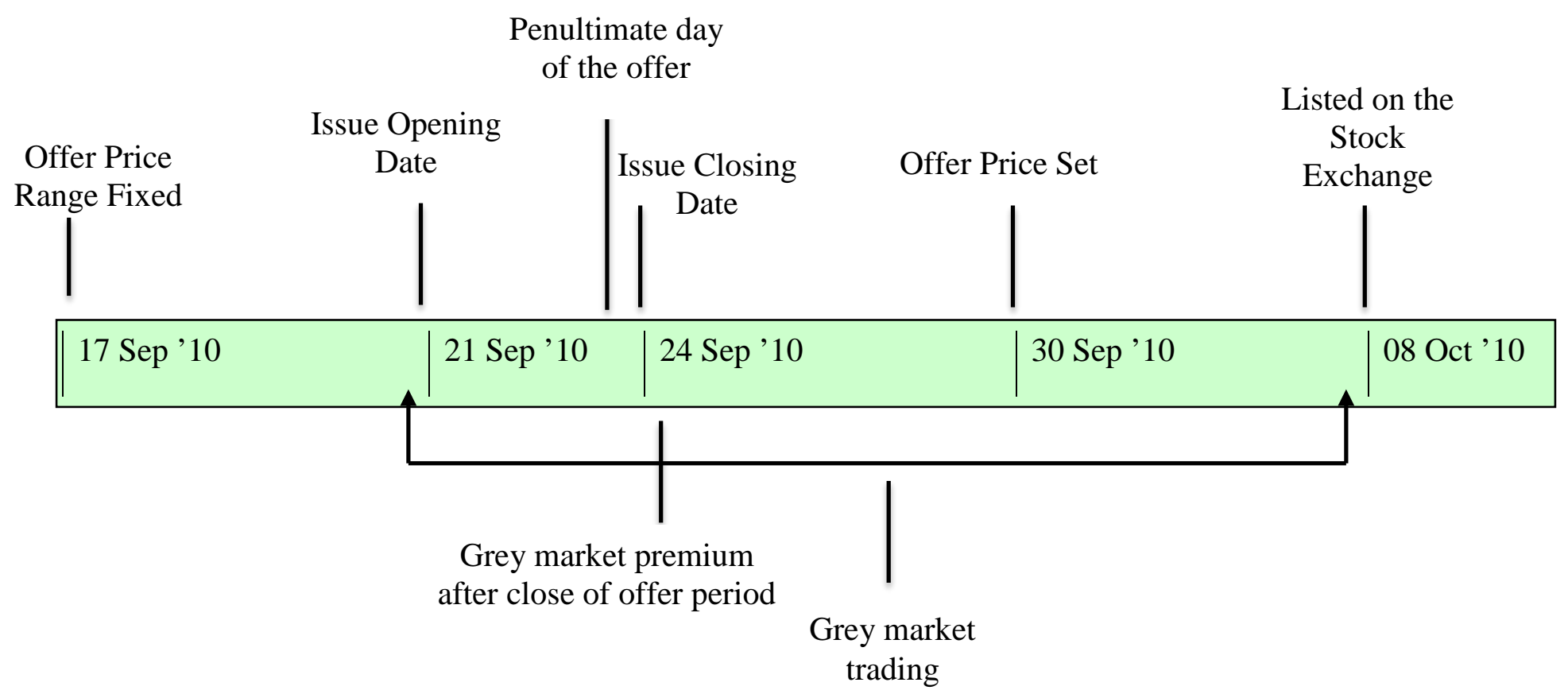




\section{Appendix B}

This appendix illustrates the two types of grey market quotes available in the Indian IPO market for Ashoka Buildcon Limited.

\begin{tabular}{|c|c|c|c|c|}
\hline Date & Offer Period & Offer Price Range & Grey market Premium & Kostak Rate \\
\hline 25 Sep 2010 & Sep 24 - Sep 282010 & INR 297 - 324 & INR 42 - 45 & INR 1,900 - 2,000 \\
\hline
\end{tabular}

The grey market premium of INR 42-45 suggests that the broker is willing to buy the stock at a premium of INR 42 at whatever the offer price is set while they are willing to sell the stock at a premium of INR 45. Following equation (1), the grey market premium in this case is $13.5 \%$ (42 $\div$ 310.5). The Kostak rate is the premium that grey market investors are willing to pay for each retail investor application which can be up to a value of INR 100,000. The Kostak rate in this case indicates that brokers are willing to buy a retail investor application for INR 1,900 and willing to sell the application for INR 2,000. 


\section{References}

Aggarwal, R., Prabhala, N.R., Puri, M., 2002. Institutional Allocation in Initial Public Offerings: Empirical Evidence. Journal of Finance 57, 1421-1442.

Aussenegg, W., Pichler, P., Stomper, A., 2006. IPO pricing with bookbuilding and a whenissued market. Journal of Financial and Quantitative Analysis 41, 829-862.

Benveniste, L.M., Spindt, P.A., 1989. How investment bankers determine the offer price and allocation of new issues. Journal of Financial Economics 24, 343-361.

Bubna, A., Prabhala, N.R., 2010. IPOs with and without Allocation Discretion: Empirical Evidence. Journal of Financial Intermediation 20, 530-561.

Chiang, Y., Qian, Y., Sherman, A., 2010. Endogenous entry and partial adjustment in IPO auctions: Are institutional investors better informed? Review of Financial Studies 23, 12001230.

Cornelli, F., Goldreich, D., 2003. Bookbuilding: How informative is the order book? Journal of Finance 58, 1415-1443.

Cornelli, F., Goldreich, D., Ljungqvist, A., 2006. Investor Sentiment and Pre-IPO Markets. Journal of Finance 61, 1187-1216.

Deb, S.S., Marisetty, V.B., 2010. Information content of IPO grading. Journal of Banking and Finance 34, 2294-2305.

Degeorge, F., Derrien, F., Womack, K., 2010. Auctioned IPOs: The US Evidence. Journal of Financial Economics 98, 177-194.

Derrien, F., 2005. IPO pricing in "hot" market conditions: Who leaves money on the table? Journal of Finance 60, 487-521.

Dorn, D., 2009. Does sentiment drive the retail demand for IPOs? Journal of Financial and Quantitative Analysis 44, 85-108. 
Field, L., Lowry, M., 2009. Institutional versus individual investment in IPOs: the importance of firm fundamentals. Journal of Financial and Quantitative Analysis 44, 489-516.

Hanley, K.W., Wilhelm, W.J., 1995. Evidence on the strategic allocation of initial public offerings. Journal of Financial Economics 37, 239-257.

Jagannathan, R., Andrei, J., Sherman, A., 2010. Why don't issuers choose IPO auctions? The complexity of indirect mechanisms. Working paper (Northwestern University).

Neupane, S., Poshakwale, S., 2012. Transparency in IPO Mechanism: Retail investors' participation, IPO pricing and returns. Journal of Banking and Finance 36, 2064-2076.

Rock, K., 1986. Why new issues are underpriced. Journal of Financial Economics 15, 187212.

Sherman, A.E., 2000. IPOs and long-term relationships: an advantage of book building. Review of Financial Studies 13, 697-714.

Sherman, A.E., 2005. Global trends in IPO methods: Book building versus auctions with endogenous entry. Journal of Financial Economics 78, 615-649. 
Table 1: Descriptive statistics

Panel A: Summary statistics of the main variables

\begin{tabular}{|c|c|c|c|c|c|c|c|}
\hline Variable & Mean & Median & 25th Pctl & 75th Pctl & Std dev & Minimum & Maximum \\
\hline Age & 14.26 & 12.50 & 8.00 & 17.02 & 10.59 & 2.02 & 92.06 \\
\hline Total assets & 7,169 & 1,702 & 712.5 & 6,641 & 16,231 & 95 & 108,000 \\
\hline Gross proceeds (Gpcds) & 3,456 & 1,115 & 512 & 2,791 & 9,629 & 140 & 100,000 \\
\hline Raw first day return $\left(\mathrm{IR}_{1}\right)$ & 0.17 & 0.09 & -0.11 & 0.33 & 0.45 & -0.69 & 2.41 \\
\hline Market adjusted first day return $\left(\mathrm{MIR}_{1}\right)$ & 0.17 & 0.06 & -0.10 & 0.33 & 0.45 & -0.93 & 2.41 \\
\hline Raw first month return $\left(\mathrm{IR}_{30}\right)$ & 0.07 & 0.03 & -0.32 & 0.30 & 0.59 & -0.87 & 3.52 \\
\hline Market adjusted first month return $\left(\mathrm{MIR}_{30}\right)$ & 0.07 & -0.02 & -0.28 & 0.29 & 0.58 & -0.88 & 3.51 \\
\hline Market returns prior to IPO (Mkt3Mw) & 0.03 & 0.04 & -0.01 & 0.08 & 0.07 & -0.23 & 0.29 \\
\hline Market volatility prior to IPO (MktVol) & 0.01 & 0.01 & 0.01 & 0.02 & 0.01 & 0.01 & 0.04 \\
\hline Oversubscription & 16.96 & 3.50 & 1.45 & 15.15 & 30.34 & 0.91 & 159.40 \\
\hline Offer price relative to price range (OfferPrice) & 0.83 & 1.00 & 0.98 & 1.00 & 0.35 & 0.00 & 1.00 \\
\hline Prior initial returns (PriorIR) & 0.22 & 0.19 & 0.08 & 0.36 & 0.18 & -0.17 & 0.60 \\
\hline Underwriter reputation (LbmRep) & 0.45 & 0.00 & 0.00 & 1.00 & 0.50 & 0.00 & 1.00 \\
\hline Grey market premium (Grey) & 0.18 & 0.07 & 0.03 & 0.17 & 0.35 & 0.00 & 3.23 \\
\hline IPO grade (Grade) & 2.58 & 2.00 & 2.00 & 3.00 & 0.82 & 1.00 & 5.00 \\
\hline
\end{tabular}

Panel A reports the summary statistics of firm and issue-specific variables of 172 Indian IPOs listed on the Bombay Stock Exchange (BSE) and/or National Stock Exchange (NSE) between 2007 and December 2011. Age is measured as the difference between the IPO year and the founding year of the sample firm (in years). Total assets is the total value of assets of the firm at the time of the IPO (in millions INR). Gross proceeds is the intended gross proceeds of the offer (in millions INR). Raw first day (month) return $\left(I R_{1} \& I R_{30}\right)$ is the return calculated between the offer price and the closing price at the end of the first day (first month) of trading. Market-adjusted first day (month) return $\left(M I R_{1} \& M I R_{30}\right)$ is the difference between raw first day return and market return, where the market return is the return on the BSE Sensex index over the same period. Market returns prior to IPO (Mkt3Mw) is the weighted average of the buy-andhold returns on the BSE Sensex index in the three months prior to the IPO issue opening date t, weights being 3 for the month before the IPO date $\left(\mathrm{M}_{\mathrm{t}-1}\right)$, 2 for the one before $\left(\mathrm{M}_{\mathrm{t}-2}\right)$, and 1 for the third month before the offering $\left(\mathrm{M}_{\mathrm{t}-3}\right)$. Market volatility prior to IPO (MktVol) is the standard deviation of the market returns one month prior to the issue opening date. Oversubscription is the ratio of the investors' demand for shares to and the total number of shares offered. Offer price relative to price range (OfferPrice) is the actual offer price normalized by the offer price range. Since Indian regulations do not allow underwriters to price the IPO outside the offer price range, the normalized offer price is always between 0 and 1 . Prior initial returns (PriorIR) is the average 
initial return for IPOs listed in the two months prior to the issue opening date of the IPO. Underwriter reputation (LbmRep) is a dummy variable which takes the value of 1 for IPOs managed by reputed underwriters and 0 otherwise. Grey market premium (Grey) is the ratio of grey market premium to and mid-point of the offer price range. Grey market premium is the difference between grey market price and the mid-point of the offer price range. We use grey market price available after the close of the offer period in our analysis. Grade is the IPO grade reflecting the quality of company fundamentals assigned by a registered credit rating agency. Grades are issued on a scale of 1-5 with 1 indicating poor and 5 indicating strong fundamentals. (1 US\$ is approximately equal to INR 62). 


\section{Panel B: Investors' participation}

\begin{tabular}{|c|c|c|c|c|c|c|c|c|}
\hline Investors' Oversubscription & Mean & Median & 25th Pctl & 75th Pctl & Std dev & Minimum & Maximum & $\begin{array}{c}\text { No. of } \\
\text { Undersubscribed } \\
\text { IPOs } \\
\end{array}$ \\
\hline Institutional investors (QIB) & 19.33 & 2.08 & 0.70 & 18.35 & 37.23 & 0.00 & 185.09 & 56 \\
\hline Non-institutional investors (NII) & 26.89 & 3.67 & 1.50 & 25.96 & 50.79 & 0.02 & 306.63 & 23 \\
\hline Retail investors (RII) & 8.58 & 3.03 & 1.08 & 9.15 & 16.10 & 0.08 & 136.82 & 45 \\
\hline
\end{tabular}

Of the 56 IPOs in which QIBs undersubscribe, retail investors undersubscribe in only 13.

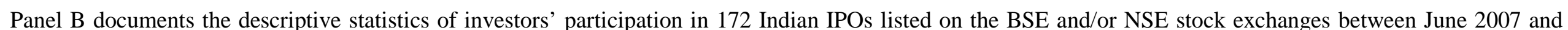

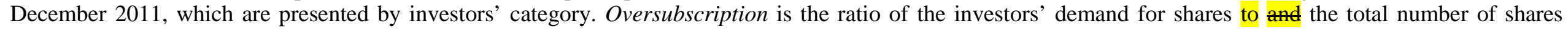
offered. 
Panel C: IPO grades, grey market premium and IPO performance

\begin{tabular}{|c|c|c|c|c|}
\hline & \multicolumn{2}{|c|}{ Mean (Median) } & Difference in & $\begin{array}{l}\text { Difference in } \\
\text { Median }\end{array}$ \\
\hline IPO Grades & Below median & $\begin{array}{l}\text { Equal to or } \\
\text { above median }\end{array}$ & & \\
\hline No. of IPOs & 88 & 84 & - & - \\
\hline Total assets & 3,206 (999) & $10,407(4,495)$ & $-7,201(0.000)$ & $-3,496(0.000)$ \\
\hline Gross proceeds (Gpcds) & $1,817(688)$ & $4,988(2,005)$ & $-3,171(0.004)$ & $-1,317(0.000)$ \\
\hline Offer price relative to price range (OfferPrice) & $0.84(1.00)$ & $0.79(1.00)$ & $0.13(0.129)$ & $0.00(0.196)$ \\
\hline Market adjusted return ( $1^{\text {st }}$ day, Sensex) & $0.19(0.09)$ & $0.12(0.06)$ & $0.07(0.323)$ & $0.03(0.458)$ \\
\hline Market adjusted return ( $1^{\text {st }}$ month Sensex) & $0.07(-0.07)$ & $0.04(-0.03)$ & $0.03(0.730)$ & $-0.04(0.569)$ \\
\hline Market adjusted return (3 month, Sensex) & $-0.09(-0.14)$ & $-0.05(-0.05)$ & $-0.04(0.112)$ & $-0.09(0.009)$ \\
\hline Market adjusted return (6 month, Sensex) & $-0.15(-0.24)$ & $-0.04(-0.08)$ & $-0.11(0.038)$ & $-0.11(0.001)$ \\
\hline Market adjusted return (12 month, Sensex) & $-0.24(-0.35)$ & $-0.09(-0.19)$ & $-0.15(0.017)$ & $-0.16(0.000)$ \\
\hline Market adjusted return (3 month, B500) & $-0.09(-0.15)$ & $-0.05(-0.04)$ & $-0.04(0.164)$ & $-0.11(0.032)$ \\
\hline Market adjusted return (6 month, B500) & $-0.14(-0.23)$ & $-0.03(-0.05)$ & $-0.11(0.026)$ & $-0.18(0.000)$ \\
\hline Market adjusted return (12 month, B500) & $-0.22(-0.32)$ & $-0.07(-0.17)$ & $-0.15(0.015)$ & $-0.15(0.000)$ \\
\hline Residual Grey Market Premium & Below median & $\begin{array}{r}\text { Equal to or } \\
\text { above median }\end{array}$ & & \\
\hline No. of IPOs & 86 & 86 & - & - \\
\hline Totals assets & $7,102(1,946)$ & $6,103(1,901)$ & $919(0.619)$ & $45(0.551)$ \\
\hline Gross proceeds (Gpcds) & $3,059(1,013)$ & $3,512(1,318)$ & $-453(0.779)$ & $-305(0.818)$ \\
\hline Offer price relative to price range (OfferPrice) & $0.71(1.00)$ & $0.95(1.00)$ & $-0.15(0.000)$ & $0.00(0.000)$ \\
\hline Market adjusted return ( $1^{\text {st }}$ day, Sensex) & $0.07(0.01)$ & $0.26(0.17)$ & $-0.19(0.002)$ & $-0.16(0.031)$ \\
\hline Market adjusted return ( $1^{\text {st }}$ month Sensex) & $-0.06(-0.10)$ & $0.19(0.10)$ & $-0.25(0.008)$ & $-0.20(0.014)$ \\
\hline Market adjusted return (3 month, Sensex) & $-0.06(-0.03)$ & $-0.10(-0.09)$ & $0.04(0.186)$ & $0.06(0.122)$ \\
\hline Market adjusted return (6 month, Sensex) & $-0.07(-0.09)$ & $-0.12(-0.20)$ & $0.05(0.144)$ & $0.11(0.059)$ \\
\hline Market adjusted return (12 month, Sensex) & $-0.13(-0.22)$ & $-0.16(-0.28)$ & $0.03(0.416)$ & $0.06(0.251)$ \\
\hline Market adjusted return (3 month, B500) & $-0.04(-0.04)$ & $-0.09(-0.09)$ & $0.05(0.216)$ & $0.05(0.147)$ \\
\hline Market adjusted return (6 month, B500) & $-0.06(-0.11)$ & $-0.10(-0.19)$ & $0.04(0.194)$ & $0.08(0.112)$ \\
\hline Market adjusted return (12 month, B500) & $-0.11(-0.20)$ & $-0.15(-0.24)$ & $0.04(0.594)$ & $0.04(0.567)$ \\
\hline
\end{tabular}


Panel C shows the post listing performance of IPOs by their grade and residual grey market premium. Regulations require IPO firms to be graded on a scale of 1 (poor fundamentals) to 5 (strong fundamentals). IPO firms with a grade of 3 or more are considered equal to or above median and firms with a grade of 2 or less are regarded as below median. For analysing the post listing performance of IPOs by grey market premium, we categorize IPOs by grouping them into below and equal to or above the residual median grey market premium. We regress grey market premium (as defined in Table 1) on IPO grade and use the residuals as the measure of grey market premium. The $1^{\text {st }}$ day and $1^{\text {st }}$ month market adjusted returns are calculated from the offer price. The 3, 6 and 12 month buy-and-hold market adjusted returns are calculated from the price at the end of the first month of listing (after 30 calendar days). Sensex refers to the BSE Sensex index comprised of the most liquid 30 stocks and B500 refers to the broader BSE 500 stock index comprised of 500 stocks. All other variables are defined in table 1 (Panel A). The statistical significance of the differences in mean (below median equal to or above median) is tested using the t-test and the significance of the difference in the median (below median equal to or above median) of the two groups of IPOs is tested using the Mann-Whitney test. p-values are reported in parentheses. 
Table 2: The determinants of retail investors’ participation in IPOs

\begin{tabular}{|c|c|c|c|c|c|c|}
\hline & \multicolumn{5}{|c|}{ Rate of Oversubscription } & \multirow{2}{*}{$\begin{array}{c}\begin{array}{c}\text { No. of } \\
\text { Bids }\end{array} \\
\text { (6) } \\
\end{array}$} \\
\hline & (1) & (2) & (3) & (4) & (5) & \\
\hline Grade & $\begin{array}{l}0.152 \\
(1.26)\end{array}$ & $\begin{array}{l}0.113 \\
(1.05)\end{array}$ & $\begin{array}{l}-0.064 \\
(-0.71)\end{array}$ & $\begin{array}{l}-0.012 \\
(-0.15)\end{array}$ & $\begin{array}{l}-0.006 \\
(-0.10)\end{array}$ & $\begin{array}{l}0.098 \\
(0.91)\end{array}$ \\
\hline GreyRes & & $\begin{array}{c}1.717 * * * \\
(3.86)\end{array}$ & & $\begin{array}{c}1.285^{* * *} \\
(2.96)\end{array}$ & $\begin{array}{c}1.108 * * * \\
(2.85)\end{array}$ & $\begin{array}{c}0.868^{* * *} \\
(3.04)\end{array}$ \\
\hline $\mathrm{QIB}_{\text {penul }}$ & & & $\begin{array}{c}0.610 * * * \\
(7.13)\end{array}$ & $\begin{array}{c}0.450 * * * \\
(4.20)\end{array}$ & $\begin{array}{c}0.396 * * * \\
(4.53)\end{array}$ & $\begin{array}{c}0.591 \text { *** } \\
(5.95)\end{array}$ \\
\hline GreyRes $\times$ Indicator & & & & & $\begin{array}{l}0.231 \\
(0.25)\end{array}$ & $\begin{array}{l}-0.013 \\
(-0.02)\end{array}$ \\
\hline $\mathrm{QIB}_{\text {penul }} \times$ Indicator & & & & & $\begin{array}{c}0.618 * * * \\
(3.06)\end{array}$ & $\begin{array}{c}0.911 \text { *** } \\
(2.96)\end{array}$ \\
\hline LnGpcds & $\begin{array}{c}-0.367 * * * \\
(-3.08)\end{array}$ & $\begin{array}{c}-0.329 * * * \\
(-4.19)\end{array}$ & $\begin{array}{c}-0.469 * * * \\
(-6.14)\end{array}$ & $\begin{array}{c}-0.393^{* * *} \\
(-5.68)\end{array}$ & $\begin{array}{c}-0.377^{* * *} \\
(-5.53)\end{array}$ & $\begin{array}{c}0.334^{* * *} \\
(3.44)\end{array}$ \\
\hline LnAge & $\begin{array}{l}0.009 \\
(0.06)\end{array}$ & $\begin{array}{l}0.013 \\
(0.12)\end{array}$ & $\begin{array}{l}0.354 \\
(0.38)\end{array}$ & $\begin{array}{l}0.057 \\
(0.68)\end{array}$ & $\begin{array}{l}0.052 \\
(0.66)\end{array}$ & $\begin{array}{l}0.148 \\
(1.42)\end{array}$ \\
\hline LbmRep & $\begin{array}{l}0.126 \\
(0.56)\end{array}$ & $\begin{array}{l}0.092 \\
(0.56)\end{array}$ & $\begin{array}{l}0.178 \\
(0.88)\end{array}$ & $\begin{array}{l}-0.063 \\
(-0.38)\end{array}$ & $\begin{array}{l}-0.111 \\
(-0.62)\end{array}$ & $\begin{array}{l}-0.066 \\
(-0.32)\end{array}$ \\
\hline Mkt3Mw & $\begin{array}{c}5.193 * * * \\
(4.34)\end{array}$ & $\begin{array}{c}2.522^{* *} \\
(2.42)\end{array}$ & $\begin{array}{c}2.917 * * * \\
(4.18)\end{array}$ & $\begin{array}{c}2.122^{* *} \\
(2.59)\end{array}$ & $\begin{array}{c}2.109 * * * \\
(2.61)\end{array}$ & $\begin{array}{c}3.394^{* * * *} \\
(3.82)\end{array}$ \\
\hline MktVol & $\begin{array}{l}-15.67 * \\
(-1.71)\end{array}$ & $\begin{array}{c}-24.58^{* *} \\
(-2.59)\end{array}$ & $\begin{array}{c}-19.32 * * * \\
(-2.05)\end{array}$ & $\begin{array}{c}-26.82 * * * \\
(-3.54)\end{array}$ & $\begin{array}{c}-27.77 * * * \\
(-3.74)\end{array}$ & $\begin{array}{l}-17.64 * \\
(-1.88)\end{array}$ \\
\hline PriorIR & $\begin{array}{c}1.797^{* * * *} \\
(4.82)\end{array}$ & $\begin{array}{c}0.793^{* *} \\
(2.40)\end{array}$ & $\begin{array}{c}1.262 * * * \\
(3.89)\end{array}$ & $\begin{array}{c}0.736^{* *} \\
(2.50)\end{array}$ & $\begin{array}{c}0.692 * * \\
(2.41)\end{array}$ & $\begin{array}{c}1.473^{* * *} \\
(4.83)\end{array}$ \\
\hline Industry FE & Yes & Yes & Yes & Yes & Yes & Yes \\
\hline Constant & $\begin{array}{c}3.413^{* *} \\
(3.27) \\
\end{array}$ & $\begin{array}{c}3.002 * * * \\
(4.03) \\
\end{array}$ & $\begin{array}{c}4.345^{* * *} \\
(6.84) \\
\end{array}$ & $\begin{array}{c}3.973^{* * *} \\
(6.14) \\
\end{array}$ & $\begin{array}{c}4.131^{* * * *} \\
(6.82) \\
\end{array}$ & $\begin{array}{c}6.488^{* * *} \\
(8.63) \\
\end{array}$ \\
\hline $\begin{array}{l}\text { Observations } \\
\text { Adjusted } R^{2}\end{array}$ & $\begin{array}{c}172 \\
0.269 \\
\end{array}$ & $\begin{array}{c}172 \\
0.563 \\
\end{array}$ & $\begin{array}{c}172 \\
0.555 \\
\end{array}$ & $\begin{array}{c}172 \\
0.654 \\
\end{array}$ & $\begin{array}{c}172 \\
0.668 \\
\end{array}$ & $\begin{array}{c}172 \\
0.773 \\
\end{array}$ \\
\hline
\end{tabular}

The retail investors' oversubscription is regressed against a set of explanatory variables as noted in equation (2) using an OLS regression framework. The dependent variable in specifications (1) - (5) is the natural log of 1 plus the retail investors' oversubscription variable which is calculated by dividing the number of shares applied for by retail investors by the number of shares offered to retail investors. The dependent variable in specification (6) is the natural log of the number of valid bids submitted by retail investors. GreyRes is the residual grey market premium obtained by regressing the grey market premium (Grey) (as defined in Table 1) on IPO grades. QIB penul is the natural log of 1 plus the institutional investors' oversubscription on the penultimate day of the offer period. GreyRes $\times$ Indicator is an interaction term to test the symmetric relationship of grey market premiums. The indicator function is set to 1 when the residual grey market premium is above median and 0 otherwise. $Q I B_{\text {penul }} \times$ Indicator is an interaction term to test the symmetric relationship of the participation of 
institutional investors. The indicator function is set to 1 when the institutional subscription is greater than 1 by the penultimate day of the offer and 0 otherwise. LnGpcds is the natural log of gross proceeds. LnAge is the natural log of 1 plus the age of the firm at the time of the IPO. LbmRep is a dummy variable which takes the value of 1 for IPOs managed by reputed underwriters and 0 otherwise. PriorIR is the average initial return for IPOs listed in the two months prior to the issue opening date of the IPO. All other variables are defined in table 1 . White heteroscedasticity-consistent t- statistics are in parentheses. $* * *, * *$ and $*$ indicate statistically significant at $1 \%, 5 \%$ and $10 \%$ respectively. 
Table 3: The determinants of institutional investors' participation in IPOs

\begin{tabular}{|c|c|c|c|}
\hline & \multicolumn{2}{|c|}{ Rate of Oversubscription } & \multirow{2}{*}{$\frac{\text { No. of Bids }}{3}$} \\
\hline & 1 & 2 & \\
\hline Grade & $\begin{array}{c}0.339 * * * \\
(3.00)\end{array}$ & $\begin{array}{c}0.325^{* * *} \\
(3.13)\end{array}$ & $\begin{array}{c}0.351^{* *} \\
(2.61)\end{array}$ \\
\hline Grade $\times$ Indicator & & $\begin{array}{l}0.0397 \\
(0.56)\end{array}$ & $\begin{array}{c}-0.0292 \\
(-0.41)\end{array}$ \\
\hline GreyRes & $\begin{array}{c}1.836^{* * *} \\
(3.62)\end{array}$ & $\begin{array}{l}-4.169 \\
(-1.27)\end{array}$ & $\begin{array}{c}-5.618 * * \\
(-2.12)\end{array}$ \\
\hline GreyRes $\times$ Indicator & & $\begin{array}{c}5.867 * * \\
(2.23)\end{array}$ & $\begin{array}{c}7.124^{* * *} \\
(2.82)\end{array}$ \\
\hline LnGpcds & $\begin{array}{l}0.092 \\
(0.28)\end{array}$ & $\begin{array}{l}0.031 \\
(0.33)\end{array}$ & $\begin{array}{c}0.409^{* * *} \\
(3.99)\end{array}$ \\
\hline LnAge & $\begin{array}{l}-0.042 \\
(-0.27)\end{array}$ & $\begin{array}{l}-0.083 \\
(-0.78)\end{array}$ & $\begin{array}{l}-0.028 \\
(-0.22)\end{array}$ \\
\hline LbmRep & $\begin{array}{c}1.175^{* * *} \\
(4.33)\end{array}$ & $\begin{array}{c}1.149 * * * \\
(4.87)\end{array}$ & $\begin{array}{c}1.172 * * * \\
(5.82)\end{array}$ \\
\hline Mkt3Mw & $\begin{array}{c}3.176^{* * *} \\
(3.06)\end{array}$ & $\begin{array}{c}3.363 * * * \\
(3.00)\end{array}$ & $\begin{array}{c}2.572^{* *} \\
(2.29)\end{array}$ \\
\hline MktVol & $\begin{array}{l}8.452 \\
(0.97)\end{array}$ & $\begin{array}{l}7.206 \\
(0.73)\end{array}$ & $\begin{array}{l}1.276 \\
(0.13)\end{array}$ \\
\hline PriorIR & $\begin{array}{l}0.785 \\
(1.54)\end{array}$ & $\begin{array}{l}0.591 \\
(1.11)\end{array}$ & $\begin{array}{l}0.389 \\
(1.04)\end{array}$ \\
\hline Industry FE & Yes & Yes & Yes \\
\hline Constant & $\begin{array}{l}-0.048 \\
(-0.06) \\
\end{array}$ & $\begin{array}{l}-0.215 \\
(-0.25) \\
\end{array}$ & $\begin{array}{l}-1.513^{*} \\
(-1.96) \\
\end{array}$ \\
\hline $\begin{array}{l}\text { Observations } \\
\text { Adjusted } R^{2}\end{array}$ & $\begin{array}{c}172 \\
0.641\end{array}$ & $\begin{array}{c}172 \\
0.640\end{array}$ & $\begin{array}{c}172 \\
0.736\end{array}$ \\
\hline
\end{tabular}

The institutional investors' oversubscription is regressed against a set of explanatory variables as noted in equation (2) using an OLS regression framework. In specifications (1) - (2) the dependent variable is the institutional investors' closing oversubscription rate (defined as the number of shares applied for by institutional investors divided by the number of shares offered to institutional investors). In specification (3) the dependent variable is the number of valid bids submitted by institutional investors. Grade $\times$ Indicator is an interaction term to test the symmetric relationship of IPO grades. The indicator function is set to 1 for firms with grades of 3 or greater and 0 otherwise. All other variables are defined in tables 1 and 2. White heteroscedasticity-consistent t- statistics are in parentheses. $* * *, * *$ and $*$ indicate statistically significant at $1 \%, 5 \%$ and $10 \%$ respectively. 
Table 4: The determinants of IPO offer price and initial returns

\begin{tabular}{|c|c|c|c|}
\hline & \multicolumn{2}{|c|}{ Offer Price } & \multirow{2}{*}{$\begin{array}{c}\text { Initial Returns } \\
\text { (3) }\end{array}$} \\
\hline & $(1)$ & $(2)$ & \\
\hline Grade & $\begin{array}{l}0.139 \\
(0.78)\end{array}$ & $\begin{array}{l}-0.154 \\
(-0.83)\end{array}$ & $\begin{array}{c}-0.049 \\
(-0.90)\end{array}$ \\
\hline GreyRes & $\begin{array}{c}11.17 * * * \\
(3.75)\end{array}$ & $\begin{array}{c}3.237 * * \\
(2.45)\end{array}$ & $\begin{array}{c}0.739 * * * \\
(7.47)\end{array}$ \\
\hline $\mathrm{QIB}_{\text {closing }}$ & & $\begin{array}{c}0.541^{* * * *} \\
(2.91)\end{array}$ & $\begin{array}{l}0.065 \\
(1.46)\end{array}$ \\
\hline $\mathrm{NII}_{\text {closing }}$ & & $\begin{array}{l}0.189 \\
(1.14)\end{array}$ & $\begin{array}{l}0.026 \\
(0.63)\end{array}$ \\
\hline RII $_{\text {closing }}$ & & $\begin{array}{c}1.203^{* *} \\
(2.31)\end{array}$ & $\begin{array}{l}0.033 \\
(0.55)\end{array}$ \\
\hline LbmRep & $\begin{array}{l}-0.616 \\
(-1.61)\end{array}$ & $\begin{array}{c}-1.219 * * \\
(-2.86)\end{array}$ & $\begin{array}{l}-0.088 \\
(-0.82)\end{array}$ \\
\hline LnGpcds & $\begin{array}{c}-0.473 * * \\
(-2.48)\end{array}$ & $\begin{array}{c}-0.532 * * * \\
(-2.93)\end{array}$ & $\begin{array}{l}-0.034 \\
(-0.99)\end{array}$ \\
\hline LnAge & $\begin{array}{l}0.154 \\
(0.75)\end{array}$ & $\begin{array}{l}0.264 \\
(1.33)\end{array}$ & $\begin{array}{l}-0.008 \\
(-0.72)\end{array}$ \\
\hline Mkt3Mw & $\begin{array}{c}5.519 * * \\
(2.18)\end{array}$ & $\begin{array}{l}4.323^{*} \\
(1.82)\end{array}$ & $\begin{array}{l}-0.303 \\
(-0.58)\end{array}$ \\
\hline MktVol & $\begin{array}{l}-4.472 \\
(-0.21)\end{array}$ & $\begin{array}{l}-13.67 \\
(-0.67)\end{array}$ & $\begin{array}{l}7.886 \\
(1.41)\end{array}$ \\
\hline PriorIR & $\begin{array}{l}-0.612 \\
(-0.88)\end{array}$ & $\begin{array}{l}-0.301 \\
(-0.46)\end{array}$ & $\begin{array}{c}0.342 * * \\
(2.26)\end{array}$ \\
\hline Industry FE & Yes & Yes & Yes \\
\hline Constant & $\begin{array}{c}6.310^{* * *} \\
(3.88)\end{array}$ & $\begin{array}{l}2.544^{*} \\
(1.72)\end{array}$ & $\begin{array}{l}0.412 \\
(1.42)\end{array}$ \\
\hline Observations & 172 & 172 & 172 \\
\hline No of Left Censored Observation & 24 & 24 & \\
\hline No of Right Censored Observations & 119 & 119 & \\
\hline LR Test: All Coeff. $=0\left(\mathrm{X}^{2}\right)$ & $108.82 * * *$ & $128.59 * * *$ & \\
\hline Pseudo $R^{2} /$ Adjusted $R^{2}$ & 0.417 & 0.497 & 0.390 \\
\hline
\end{tabular}


t- statistics are in parentheses for specification (3). ${ }^{* * *},{ }^{* *}$ and $*$ indicate statistically significant at $1 \%, 5 \%$ and $10 \%$ respectively. 
Table 5: The determinants of aftermarket returns

\begin{tabular}{|c|c|c|c|c|c|c|}
\hline & \multicolumn{3}{|c|}{ Sensex adjusted } & \multicolumn{3}{|c|}{ BSE 500 adjusted } \\
\hline & $\begin{array}{l}3 \mathrm{~m} \\
(1)\end{array}$ & $\begin{array}{l}6 \mathrm{~m} \\
(2)\end{array}$ & $\begin{array}{c}12 \mathrm{~m} \\
(3)\end{array}$ & $\begin{array}{l}3 \mathrm{~m} \\
(4)\end{array}$ & $\begin{array}{l}6 \mathrm{~m} \\
(5) \\
\end{array}$ & $\begin{array}{c}12 \mathrm{~m} \\
(6) \\
\end{array}$ \\
\hline Grade & $\begin{array}{c}0.033^{*} \\
(1.94)\end{array}$ & $\begin{array}{c}0.085 * * \\
(2.01)\end{array}$ & $\begin{array}{c}0.087 * * \\
(2.08)\end{array}$ & $\begin{array}{c}0.033^{*} \\
(1.87)\end{array}$ & $\begin{array}{c}0.098 * * \\
(2.15)\end{array}$ & $\begin{array}{c}0.087^{* *} \\
(2.09)\end{array}$ \\
\hline GreyRes & $\begin{array}{c}-0.101 * * \\
(-2.40)\end{array}$ & $\begin{array}{c}-0.049 * \\
(-1.93)\end{array}$ & $\begin{array}{l}-0.037 \\
(-0.42)\end{array}$ & $\begin{array}{c}-0.127^{* *} \\
(-2.02)\end{array}$ & $\begin{array}{c}-0.048 * \\
(-1.86)\end{array}$ & $\begin{array}{l}-0.036 \\
(-0.44)\end{array}$ \\
\hline $\mathrm{QIB}_{\text {closing }}$ & $\begin{array}{l}0.019 \\
(0.54)\end{array}$ & $\begin{array}{l}0.019 \\
(0.71)\end{array}$ & $\begin{array}{l}0.014 \\
(0.31)\end{array}$ & $\begin{array}{l}0.013 \\
(0.46)\end{array}$ & $\begin{array}{l}0.015 \\
(0.56)\end{array}$ & $\begin{array}{l}0.014 \\
(0.40)\end{array}$ \\
\hline $\mathrm{RII}_{\text {closing }}$ & $\begin{array}{l}-0.033 \\
(-0.69)\end{array}$ & $\begin{array}{l}-0.047 \\
(-0.71)\end{array}$ & $\begin{array}{l}-0.006 \\
(-0.09)\end{array}$ & $\begin{array}{l}-0.028 \\
(-0.59)\end{array}$ & $\begin{array}{l}-0.049 \\
(-0.63)\end{array}$ & $\begin{array}{l}-0.006 \\
(-0.09)\end{array}$ \\
\hline LbmRep & $\begin{array}{l}-0.007 \\
(-0.15)\end{array}$ & $\begin{array}{l}0.042 \\
(0.50)\end{array}$ & $\begin{array}{l}-0.033 \\
(-0.32)\end{array}$ & $\begin{array}{l}-0.009 \\
(-0.15)\end{array}$ & $\begin{array}{l}0.037 \\
(0.45)\end{array}$ & $\begin{array}{l}-0.031 \\
(-0.30)\end{array}$ \\
\hline LnGpcds & $\begin{array}{l}-0.031 \\
(-1.27)\end{array}$ & $\begin{array}{c}-0.074^{*} \\
(-1.97)\end{array}$ & $\begin{array}{l}-0.078 \\
(-1.26)\end{array}$ & $\begin{array}{l}-0.034 \\
(-1.33)\end{array}$ & $\begin{array}{c}-0.076^{*} \\
(-1.92)\end{array}$ & $\begin{array}{l}-0.069 \\
(-1.41)\end{array}$ \\
\hline LnAge & $\begin{array}{l}0.018 \\
(0.24)\end{array}$ & $\begin{array}{l}0.074 \\
(1.22)\end{array}$ & $\begin{array}{l}0.083 \\
(1.13)\end{array}$ & $\begin{array}{l}0.022 \\
(0.56)\end{array}$ & $\begin{array}{l}0.078 \\
(1.14)\end{array}$ & $\begin{array}{l}0.088 \\
(1.21)\end{array}$ \\
\hline PriorIR & $\begin{array}{l}-0.101 \\
(-0.80)\end{array}$ & $\begin{array}{l}-0.217 \\
(-1.31)\end{array}$ & $\begin{array}{l}-0.362 \\
(-1.27)\end{array}$ & $\begin{array}{l}-0.112 \\
(-0.88)\end{array}$ & $\begin{array}{l}-0.197 \\
(-1.18)\end{array}$ & $\begin{array}{l}-0.326 \\
(-1.14)\end{array}$ \\
\hline Industry FE & Yes & Yes & Yes & Yes & Yes & Yes \\
\hline Constant & $\begin{array}{l}0.017 \\
(0.64) \\
\end{array}$ & $\begin{array}{l}0.023 \\
(0.39) \\
\end{array}$ & $\begin{array}{l}0.026 \\
(0.07) \\
\end{array}$ & $\begin{array}{l}0.061 \\
(0.53) \\
\end{array}$ & $\begin{array}{l}0.040 \\
(0.36) \\
\end{array}$ & $\begin{array}{l}0.022 \\
(0.06) \\
\end{array}$ \\
\hline $\begin{array}{l}\text { Observations } \\
\text { Adjusted } R^{2}\end{array}$ & $\begin{array}{c}172 \\
0.015\end{array}$ & $\begin{array}{c}172 \\
0.023\end{array}$ & $\begin{array}{c}172 \\
0.027\end{array}$ & $\begin{array}{c}172 \\
0.019\end{array}$ & $\begin{array}{c}172 \\
0.024\end{array}$ & $\begin{array}{c}172 \\
0.023\end{array}$ \\
\hline
\end{tabular}


The market adjusted buy-and-hold 3, 6 and 12 months returns are regressed against a set of explanatory variables as described in equation (5) using OLS regression. The returns are calculated from the price at the end of the first month of listing (after 30 calendar days). The Sensex is the market index representing 30 most liquid stocks and the BSE 500 is the index of the 500 stocks listed on the Bombay Stock Exchange. All variables are defined in tables 1, 2 and 4. White heteroscedasticityconsistent t- statistics are in parentheses. ${ }^{* * *},{ }^{* *}$ and $*$ indicate statistically significant at $1 \%, 5 \%$ and $10 \%$ respectively. 